\title{
EFFECT OF PRESSURE INFILTRATION OF CALCIUM CHLORIDE ON POSTHARVEST STORAGE LIFE OF AVOCADO (Persia americana Mill)
}

\author{
W. R. K. D. W. K. V. Wickramasinghe1, W. A. A. S. Abayagunawardane ${ }^{2}$ \\ and P. K. Dissanayake ${ }^{2}$
}

\begin{abstract}
Fruits of avocado var. Pollock, harvested at physiologically matured stage, were pressure infiltrated with four concentrations of aqueous solutions of $\mathrm{CaCl}_{2}(0 \%, 2 \%, 4 \%$ and $6 \%)$ at $250 \mathrm{mmHg}$ pressure with a view of improving the shelf-life and quality. Fruits were assessed for firmness, ascorbic acid, and total $\mathrm{Ca}$ in peel and flesh. Postharvest pressure infiltration of $\mathrm{CaCl}_{2}$ extended the storage life and slowed down the ripening process of avocado. Ripening of fruits was delayed for 2-3 days with pressure infiltration of $\mathrm{CaCl}_{2}$ compared with untreated fruits, while treated fruits maintained considerable quantity of ascorbic acid at ripened stage. Sensory evaluation revealed that there were no significant differences among treatments for sweetness, color, odor and hardness of fruits.
\end{abstract}

\section{INTRODUCTION}

Avocado (Persia americana, Mill) is a very important fruit, not only in nutrient point of view but also play a major role in maintaining human health. The fruit contains unsaturated fatty acids which displace harmful Low Density Lipoproteins from the blood reducing cardiac problems. Postharvest handling is a critical issue in avocado due to the delicate nature of ripened fruits. Postharvest losses may take place at any stage of handling from harvesting, storage, marketing to final delivery to the consumer. The short storage life and perishable nature of the fruit limits long distance delivery from farm to the market and increase wastage.

Calcium chloride treatments have shown in increasing shelf-life of fruits, mainly by making cell wall less accessible to pathogens and softening enzymes. Calcium sprays have been applied on many fruits and vegetables to reduce physiological disorders and postharvest diseases (Sharples and Johnson, 1977;
Abeywickrama, 2009). Firming and resistance to softening resulting from addition of calcium have been attributed to the stabilization of membrane systems and the formulation of calcium pectates, which increase the rigidity of measocarp and cell wall of the fruit (Jackman and Stanley, 1998).

Increased $\mathrm{Ca}^{+2}$ levels have shown to reduce respiration and rate of ethylene production in variety of fruits. $\mathrm{CaCl}_{2}$ application in fruits can be done in three ways as dipping, vacuum or reduced pressure and pressure infiltration (Senevirathna and Daundasekara, 2010). However, there are some differences in effectiveness of $\mathrm{CaCl}_{2}$ application as a postharvest treatment in crops.

Although uptake of Ca in "Hass" and "Fuerte" avocado were greatly enhanced with vacuum infiltration of $8 \% \mathrm{CaCl}_{2}$ solution, higher than $4 \% \mathrm{CaCl}_{2}$ did not delay the ripening process (Boonyakiay et al., 1994). Two avocado

\footnotetext{
1 Regional Agriculture Research and Development Centre, Bandarawela, Sri Lanka.

2 Faculty of Agricultural Science, Sabaragamuwa University of Sri Lanka, Belihuloya, Sri Lanka.
} 
cultivars "Reed" and "Monoroe" grown in South Florida have short postharvest life, because these varieties ripened within a short time after harvest. Davenport (1984) conducted another calcium infusion experiment with these varieties and his results are in line with Boonyakiats findings, where $4 \% \mathrm{CaCl}_{2}$ vacuum infiltration inhibited ripening of avocado and keep good eating qualities. According to Wills and Tirmazi (1982), infiltration with $\mathrm{CaCl}_{2}$ is effective in delaying the ripening of avocado at $20{ }^{\circ} \mathrm{C}$ however, the pressure required for infiltration differs with varieties. Optimum $\mathrm{Ca}$ uptake with good eating qualities was assured in variety "Fuerte" at $375 \mathrm{mmHg}$, while 250 $\mathrm{mmHg}$ was required for "Hass" at $4 \% \mathrm{CaCl}_{2}$ level.

Keeping in mind the usefulness of $\mathrm{CaCl}_{2}$ treatments in delaying the ripening process of fruits, the present study was undertaken to evaluate the effectiveness of postharvest pressure infiltration of different concentrations of $\mathrm{CaCl}_{2}$ to delay the ripening process of avocado.

\section{MATERIALS AND MATHODS}

Mature but green avocado fruits (var. Pollock) harvested from the research field at Regional Agriculture Research andDevelopment Centre, Bandarawela were immediately transferred to the horticulture laboratory of the centre. Fruits of uniform size were selected, washed in running tap water, cleaned, and stems were trimmed out. Then they were separated into four batches, each having three fruits per replicate. Calcium chloride pressure infiltration was performed by slightly modifying the method of Perera and Karunarathne (2002). Fruits were immersed in $\mathrm{CaCl}_{2}$ solutions $(2 \%$, $4 \%$ and $6 \%$ concentrations) and pressure (250 $\mathrm{mmHg}$ ) was applied for 10 minutes using an autoclave (T.S.I. N.C., England, Thermostat range $\left.\pm 20^{\circ} \mathrm{C}\right)$. Fruits in the control were immersed in distilled water $\left(0 \% \mathrm{CaCl}_{2}\right)$ and pressurized in the same manner. Treated fruits allowed draining for 30 minutes upon removal from the immersed solutions. They were stored in clean, dry plastic trays $(30 \mathrm{~cm}$ diameter) at room temperature $\left(23-27^{\circ} \mathrm{C}\right)$ and $\mathrm{RH}$ of $70-80 \%$. Experiment was arranged in completely randomized design (CRD) with three replicates.

Quality characteristics such as fruit softening, ascorbic acid and $\mathrm{Ca}$ content were determined according to standard procedures. Sensory parameters as color, hardiness, sweetness and odor were evaluated by five panelists selected from RARDC, Bandarawela.

\section{Shelf life of fruits}

Shelf life of fruits was estimated as numbers of days taken to reach the consumer ripe stage. Fruit softening is the commonly used primary indicator of ripeness. The degree of ripeness was estimated subjectively by softening of the flesh as judged by hand pressure and translated to numerical values as; hard unripe (pressure $<12 \mathrm{~kg}$ if measured with penetrometer) $=$ 1 ; starting to soften $=2$; medium hard $=3$; medium $\operatorname{soft}=4 ;$ soft $=5$. A fruit with a score of 5 was considered consumer ripe (Tirmazi and Wills 1982).

\section{Ascorbic acid (vitamin C) content}

Ascorbic acid content in the fruit flesh was determined following the method of Kirk and Sawyer (1991). Ten gram of flesh from each fruit was mixed with $10 \mathrm{ml}$ of metaphosphoric acid and juice was extracted. Extracted juice was titrated with indophenol dye solution till a faint pink color persists for 15 seconds. Indophenol dye solution titrated with vitamin $\mathrm{C}$ solution was used as the standard. Calculate the $\mathrm{mg}$ of vitamin $\mathrm{C}$ equivalent to $1 \mathrm{ml}$ of dye solution. Finally, this factor was used to calculate the vitamin $\mathrm{C}$ content in $\mathrm{mg}$ per $10 \mathrm{~g}$ of the sample. 


\section{Determination of Calcium content of avocado flesh and peel tissues}

Peel and flesh tissues were removed separately and dried in oven at $60^{\circ} \mathrm{C}$ until constant weight. Dry ash method (Barthakur and Baruah, 1997) was used to prepare the tissues for $\mathrm{Ca}$ determination. The amount of calcium was obtained by Iron meter (3205, Jenway, UK). Tissue $\mathrm{Ca}^{+2}$ contents were expressed as ppm.

\section{Sensory Evaluation}

The sensory characters such as color, odor, sweetness and hardiness were judged by a panel of five people. Samples were analyzed using a five-point hedonic scale basis: 1- Extremely dislike, 2-dislike, 3-nor dislike or like, 4-like and 5- Extremely like, (Centinakaya et al., 2006). Data taken from sensory evaluation were subjected to Friedman analysis using MINITAB 14.

\section{RESULTS AND DISCUSSIONS}

Calcium chloride pressure infiltration delayed avocado fruit ripening for 2-3 days compared to control (Table 01). However, the results reported here disagree with other workers, who observed up to $50 \%$ delayed ripening of "Fuerte" and "Hass" fruits with vacuum infiltration of $4 \% \mathrm{CaCl}_{2}$ solution (Wills and Tirmazi, 1982; Boonyakiay et al., 1994). The differences observed in the present experiment may be due to the method used for calcium chloride application. Vacuum infiltration may be a more effective method than pressure infiltration to inject $\mathrm{Ca}$ into fruits. Wills et al., (1977) reported that threefold increase of calcium level is required to produce any noticeable retardation of fruit ripening in green tomato cultivar "Rouge de Mamande", at $20^{\circ} \mathrm{C}$. However higher concentrations of calcium chloride stood at par with untreated fruits.

\section{Ascorbic acid (vitamin C) content of fruits}

Ascorbic acid content was determined in unripe fruits, and in $\mathrm{Ca}$ treated and control fruits after 14 days of treatment (Table 02). Unripe fruits had the highest Vitamin C content (2.00 $\mathrm{mg} / 10 \mathrm{~g}$ of fresh weight). Although there was a significant $(\mathrm{P}<0.05)$ decrease in ascorbic acid content of fruits during ripening, fruits infiltrated with $6 \% \mathrm{CaCl}_{2}$ had significantly higher retention of ascorbic acid than in control fruits. Guaglianoni et al., (2009) observed decreased ascorbic acid content during storage of Atemoya fruits. However, Mahumud et al., (2008) reported that papaya fruits treated with higher doses of calcium had highest ascorbic acid content than untreated fruits. The present study agrees with both findings. At consumerripe stage, the highest vitamin $\mathrm{C}$ content was observed in fruits treated with $6 \% \mathrm{CaCl}_{2}$ (Table 01). Ascorbic acid plays an important role in human health (Oguntibeju, 2008) and fruits with high ascorbic acid improve their taste and quality. Therefore treating avocado with $\mathrm{CaCl}_{2}$ not only delays its ripening but also increases the nutritive value.

Table 01: Effect of pressure infiltration of $\mathrm{CaCl}_{2}$ on ripening of "Pollock" avocado

\begin{tabular}{lc}
\hline Treatment & Time taken to reach consumer ripe stage (days) \\
\hline Control & $11.333 \mathrm{a}$ \\
& $14.000 \mathrm{~b}$ \\
$2 \% \mathrm{CaCl}_{2}$ & $14.000 \mathrm{~b}$ \\
$4 \% \mathrm{CaCl}_{2}$ & $14.000 \mathrm{~b}$ \\
$6 \% \mathrm{CaCl}_{2}$ & 10.825 \\
$\mathrm{CV}$ & \\
\hline
\end{tabular}

Means with the same letter are not significantly different at 0.05 level according to Duncan's multiple range test 
Table 02: Effect of pressure infiltration $(250 \mathrm{mmHg})$ of $\mathrm{CaCl}_{2}$ on ascorbic acid content of "Pollock" avocado.

\begin{tabular}{ll}
\hline Treatment & Ascorbic acid content (mg/10 g fresh weight) \\
\hline & \\
Control Fruit at unripe stage & $2.00 \mathrm{a}$ \\
Control fruit at ripe stage & $0.06 \mathrm{c}$ \\
$2 \%$ calcium chloride at ripe stage & $0.07 \mathrm{c}$ \\
$4 \%$ calcium chloride at ripe stage & $0.06 \mathrm{c}$ \\
$6 \%$ calcium chloride at ripe stage & $0.17 \mathrm{~b}$ \\
CV & 4.96 \\
\hline
\end{tabular}

Means with the same letter are not significantly different at 0.05 level according to DMRT

Table 03: Uptake of $\mathrm{Ca}$ by "Pollock" avocados in $\mathrm{CaCl}_{2}$ solution. Each value is the mean of duplicate on 3 composite samples of 5 fruits.

\begin{tabular}{lll}
\hline Treatment & Peel (ppm) & Flesh (ppm) \\
\hline & & \\
Control & 0.10 & 0.20 \\
$2 \% \mathrm{CaCl}_{2}$ & 0.19 & 0.38 \\
$4 \% \mathrm{CaCl}_{2}$ & 0.21 & 0.50 \\
$6 \% \mathrm{CaCl}_{2}$ & 0.23 & 0.51 \\
\hline
\end{tabular}

\section{Calcium content of avocado flesh and peel tissues}

Calcium uptake of "Pollock" avocado after pressure infiltration of $\mathrm{CaCl}_{2}$ is shown in Table 03. Ca content of the peel and flesh was high in treated fruits compared to untreated fruits. On the other hand, slightly higher level of Ca was detected in avocado flesh. Senevirathna and Daundasekara (2010), in their dye penetration test on tomato, revealed that most of the treatment solutions enter into tomato fruits through the stem end scar. Hence, the large stem end scar of avocado fruits might provide more access for $\mathrm{Ca}$ to penetrate more into the flesh. Present study revealed that calcium uptake of the fruit by pressure infiltration was more successful.

\section{Sensory analysis of fruits}

Results of sensory analysis are given in Figure 01 . There were no significant differences observed between treatments on color, sweetness, odor and hardiness of avocado fruits.

Sensory analysis showed that all treatments were acceptable without significant difference in the overall sweetness, odor, color and hardiness $(\mathrm{P}<0.05)$. Therefore it can be suggested that $\mathrm{CaCl}_{2}$ pressure infiltration have no effect on the sensory qualities of avocado fruits. Hence $\mathrm{CaCl}_{2}$ pressure infiltration can be used to delay ripening of avocado fruits without any effect of fruit acceptability parameters. 


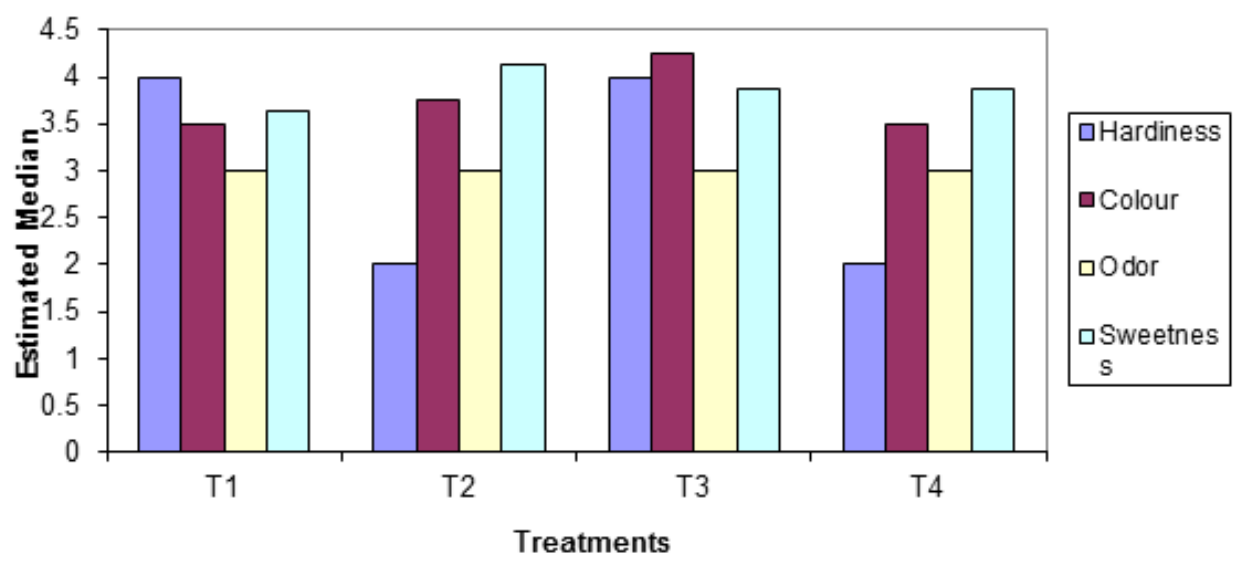

Figure 01. Mean values of sensory parameters of treated avocado (values are means of 5 replicates). $T_{1}=$ Control, $T_{2}=2 \%$ Calcium chloride, $T_{3}=4 \%$ Calcium chloride, $T_{4}=6 \%$ Calcium chloride

\section{CONCLUSION}

Fruits treated with calcium chloride using the fruit. However, further studies are in need pressure infiltration delayed fruit ripening to identify the optimum $\mathrm{CaCl}_{2}$ concentration, for 2-3 days than that of untreated fruits. pressure level and method of application to Further, the calcium treatments maintained delay the ripening process of avocado fruits considerable level of ascorbic acid in fruits at as different cultivars of fruit could respond ripened stage ensuring the nutrition value of differently to the treatments.

\section{REFERENCES}

Abeywickrama, K. (2009). Postharvest Concepts and Research Trends. Godage International Publishers (Pvt) Ltd, Colombo, Sri Lanka.

Barthakur, H.P. and Baruah, T.C. (1997). Text Book of Soil Analysis. Vikas Publishing house (Pvt)Ltd. New dehli.

Boonyakiay, D., Caffin, N. and Yuen, C.M.C. (1994). Effect of Calcium Infiltration on Ripening of Avocado of Different Maturities. Australian journal of Experimental Agriculture 34(1):123-126.

Centinayak, A., Elmali, E., Karadagoglu, G. and Yaman, H. (2006). Prediction of consumer acceptability of flavoured youghurt by sensory measures in Turkey. Pakistan Journal of Nutrition 5(1): 93-96.

Davenport, T.L. (1984). Studies on avocado fruit ripening using calcium. Procceeding of the Florida State Horticultural Society 97:329-330. 
Guaglianoni, D.G., Neves, V.A., Silva, M.A.D.and Torres, L.M.A.R. (2009). Effect of heat treatment and calcium on postharvest storage of atemoya Fruits. Alimentos e Nutricáo 20 (3):.359-367.

Jackman, R.1. and Stanely, D.W. (1998). Perspective in the textured evaluation of plants foods. Trends Food Science Technology 6:83-86

Kirk, R.S. and Sawyer, R. (1991). Pearson's Composition and Analysis of Foods. $9^{\text {th }}$ ed. Longman Group. UK.

Mahumad, T.M.M., Mohamed, Zaki, A.R., Rahaman, A.E.A., Raqeeb, A.E. and Syed Omar, S.R. (2008). Effect of different concentrations and application of calcium on storage life and physiochemical characteristics of papaya. American Journal of Agricultural and biological Sciences 3 (3): 526-533.

Oguntibeju, O.O. (2008). The biochemical, physiological and therapeutic roles of ascorbic acid. African Journal of Biotechnology 7 (25): 4700-4705.

Perera, A.N. and Karunarathne, A.M. (2002). Postharvest calcium treatments do not help to increase shelf-life of bananas. Fruit 7: 87-94.

Senevirathna, P.A.W.A.N.K. and Daundasekara, W.A.M. (2010). Effects of postharvest calcium chloride vacuum infiltration on the shelf life and quality of tomato (cv. Thilina). Ceylon Journal of science (Biological Sciences) 39(1): 35-44.

Sharples, R.O. and Johnson, D. S. (1977). The influence of calcium on senescence changes in apples. Annuals of Applied Biology 85:450-453.

Wills, R.B.H. and Tirmazi, S.I.H. (1982). Inhibition of ripening of avocados with calcium. Australian Journal of Scientia Horticiltiurae 16: 323-330.

Wills, R.B.H., Tirmazi, S.I. and Scott, K.J. (1977). Use of calcium to delay ripening of tomatoes, Hort Science 12: 551-552. 